\title{
A LITERATURA COMO FORMA DE DESENVOLVIMENTO AFETIVO, COGNITIVO E SOCIAL NA EDUCAÇÃO INFANTIL: O OLHAR DOCENTE
}

\section{ARTIGO ORIGINAL}

SILVA, Haile Dalla Cunha Saugo ${ }^{1}$, DESIDÉRIO, Taís Regina ${ }^{2}$

SILVA, Haile Dalla Cunha Saugo. DESIDÉRIO, Taís Regina. A literatura como forma de desenvolvimento afetivo, cognitivo e social na educação infantil: o olhar docente. Revista Científica Multidisciplinar Núcleo do Conhecimento. Ano. 06, Ed. 10, Vol. 04, pp. 178-197. Outubro 2021. ISSN: 2448-0959, Link de acesso: https://www.nucleodoconhecimento.com.br/educacao/desenvolvimento-afetivo, DOI: 10.32749/nucleodoconhecimento.com.br/educacao/desenvolvimento-afetivo

\section{RESUMO}

O presente trabalho é resultado de uma pesquisa de campo realizada que teve como principal objetivo analisar de que forma o professor utiliza-se da literatura infantil para o desenvolvimento afetivo, cognitivo e social das crianças. Tendo em vista este cenário, o presente artigo tem como questão norteadora: o pedagogo, fazendo uso da literatura, consegue perceber o desenvolvimento afetivo, cognitivo e social das crianças? Para tal, foi realizada uma revisão de literatura e estudo de caso com abordagem qualitativa de pesquisa, sendo que, para produção de dados foram utilizados observação participante e entrevista. O contexto da pesquisa foi uma escola de Educação Infantil do município de Matupá, Estado de Mato Grosso. A análise dos dados permitiu inferir que os professores da Educação Infantil possuem a percepção de como o uso da literatura no cotidiano escolar auxilia no desenvolvimento do indivíduo, favorecendo sua comunicação oral, enriquecendo o vocabulário e mostrando a importância da família como auxiliadora nesse processo

\footnotetext{
${ }^{1}$ Pós-graduada em Educação Infantil; graduada em Pedagogia. ORCID: 0000-0002-0731-3881

${ }^{2}$ Orientadora.
}

RC: 99019

Disponível em:

https://www.nucleodoconhecimento.com.br/educacao/desenvolvimento-afetivo 
de leitura, tornando um momento único de atenção e afeto. Os pedagogos demonstraram, através de suas falas, que buscam tornar a literatura algo prazeroso e produtivo, pois as crianças trocam experiências entre si, se socializando e apreciando a leitura. Sendo assim, pode-se concluir que a literatura se torna complemento essencial de aprendizado, através de metodologias e recursos que despertem o interesse das crianças pequenas ao hábito da leitura, contribuindo diretamente na formação do futuro leitor e no desenvolvimento afetivo, cognitivo e social.

Palavras-chave: Educação Infantil, literatura Infantil, desenvolvimento da criança, olhar docente.

\section{INTRODUÇÃO}

Muito se fala da importância de ler para as crianças, que elas gostam muito de ouvir histórias e de inventá-las, no entanto, há de se perguntar, se quem lê para a criança conhece a real importância desse ato.

A criança que desde muito cedo é apresentada ao mundo da leitura, destaca-se dentre as demais em muitos aspectos, pois a leitura é capaz de transformar o indivíduo em sujeito ativo e mudar o contexto em que ele está inserido.

Ouvir histórias é muito importante na formação de qualquer criança, é o início da aprendizagem para ser um leitor e, tornar-se um leitor é começar a compreender e interpretar o mundo. Por isso precisamos ler histórias para as crianças, sempre, sempre... (ABRAMOVICH, 1993, p.17)

Apesar de ser integrada no cotidiano escolar desde a educação infantil, a literatura necessita de instrumentos que despertem a atenção das crianças para que estas estejam interessadas em ouvir e ler, estimulando assim o gosto pela leitura, desta forma, favorecendo um aprendizado consistente e duradouro, pois a criança que aprende brincando, possui um aprendizado mais significativo.

As autoras Cramer e Castle (2011) acreditam ser papel do professor criar em sala de aula um ambiente agradável, uma forma de motivar o aluno a ir de encontro a leitura

RC: 99019

Disponível em:

https://www.nucleodoconhecimento.com.br/educacao/desenvolvimento-afetivo 
através do afeto com ela. "Dentro da sala de aula, não há modelo mais efetivo do que um professor que realmente ame os livros e a leitura." (CRAMER e CASTLE, 2011, p.111).

A pessoa que lê para as crianças, precisa também ter gosto pela leitura, tornar aquele momento instigante, despertar a curiosidade, fazer a criança interagir com o que ouve, levá-lo a fazer parte daquilo que é falado, incentivando-o a se envolver naquele momento mágico, sem esquecer de ter o cuidado de mostrar a todos os ouvintes as ilustrações, pois esta é sem dúvida, parte importante na literatura infantil, dando ainda mais riqueza e encanto aos livros voltados para esse público.

A partir das ideias citadas, percebe-se a importância de atividades prazerosas com a introdução da Literatura Infantil, desde o berçário, onde o primeiro contato com os livros é de suma importância, mesmo que nesse contato, o livro seja apenas visto como um brinquedo.

Esta pesquisa visa enfocar de que forma o professor utiliza-se da literatura infantil para o desenvolvimento afetivo, cognitivo e social das crianças trazendo toda a importância que a Literatura Infantil ocupa no âmbito escolar, fundamental na construção de conhecimentos, informação e leitura de mundo.

Tendo em vista este cenário, o presente artigo tem como questão norteadora: o pedagogo, fazendo uso da literatura, consegue perceber o desenvolvimento afetivo, cognitivo e social das crianças?

Com base nesta problemática, esta pesquisa tem como objetivo, através de estudo de caso, sendo a coleta de dados feita através de entrevista, analisar se o pedagogo fazendo uso da literatura consegue perceber esses desenvolvimentos, de que forma o professor vê a importância da literatura infantil para o desenvolvimento afetivo, cognitivo e social das crianças.

Tendo como objetivos específicos: identificar as concepções da Literatura Infantil presentes no Brasil a partir do século XX, e os principais nomes dessa época. Como 
se deu a literatura infantil, como é sua história, origem. Qual o motivo de se ler para bebês e como o professor pode ser um auxiliador literário e como isso ocorre.

\section{LITERATURA INFANTIL DO BRASIL NO SÉCULO XX}

No Brasil, não havia livros destinados ao público infantil até 1808, segundo Costa (2009, p. 123) somente com a implantação da Imprensa Régia é que começam as publicações de livros voltados às crianças brasileiras.

Anteriormente, apenas uma pequena elite econômica tinha o privilégio de usufruir de uma literatura impressa, mesmo que não fosse destinada ao público infantil; por esse motivo, a literatura oral predominou por muitos anos.

A partir do século XIX, algumas obras começaram a circular, traduzidas por Carlos Jansen, pioneiro na tradução e adaptação de textos como Contos Seletos das Mil e uma Noites (1882), Robinson Crusoé (1885), As aventuras do Celebérrimo Barão de Münchausen (1891) entre outros. Contos Pátrios (1904) de Olavo Bilac e Coelho Neto são editados, e é lançado Histórias da Nossa Terra, Contos Infantis, de Júlia Lopes de Almeida. Os Livros do Povo (1861) de Antônio Marques Rodrigues, foi o primeiro livro de grande repercussão escolar e Contos da Carochinha (1896) de Figueiredo Pimentel, reunindo narrativas de fadas, fábulas e contos exemplares, foi a primeira coletânea brasileira de Literatura Infantil organizada com expressa intenção de tradução brasileira segundo Coelho (1991 apud COSTA, 2009, p.124).

Costa (2009, p. 124), relata que com o romance Saudade (1919) Tales de Andrade encerra este período de origem da Literatura Infantil brasileira, com características bem brasileiras do tempo de infância no interior do estado de São Paulo e com intensa afetividade no texto relatando o tempo de criança, lembrando um pouco a forma que a Itália tratava a educação dos meninos no final do século XIX em Coração de Edmundo de Amicis.

Em 1921, Monteiro Lobato publica A menina do Narizinho Arrebitado, onde a imaginação, enredo, linguagem visual, graça e humor na expressão linguística, 
mudava o conceito de Literatura Infantil no Brasil. Esta obra foi considerada o maior clássico da Literatura Infantil brasileira, Monteiro Lobato conseguiu criar personagens tipicamente brasileiros em suas obras, desde a relação com a natureza, afetividade, comportamentos, linguagem e enriquecido pelo folclore brasileiro. Já em 1931 Reinações de Narizinho, com personagens representando seres humanos, e que representam com a mesma textura das personagens inventadas, "existem com a mesma verdade dentro do universo de faz-de-conta que Lobato criou" (COELHO, 1991 apud COSTA, 2009, p. 126).

Segundo Costa (2009), "a literatura brasileira está marcada pelo registro das peculiaridades locais. Mas a principal marca da Literatura Infantil é a obra de Monteiro Lobato, dividindo-a em antes e depois do autor" (COSTA, 2009, p.127).

Percebemos através da citação de Costa (2009), que Monteiro Lobato mudou a forma de escrever literatura infantil, por que além de levar o conhecimento das tradições as crianças, queria questionar as verdades, abrindo espaço para nova ideias.

\section{HISTÓRIA DA LITERATURA INFANTIL}

Segundo Coelho (1991) apud Costa (2009, p. 147) o surgimento da Literatura deuse através da tradição oral, no conto e reconto de lendas, mitos, folclore e narrativas que servissem de exemplos, já que a intenção das narrativas era a de transmitir ideias, herança cultural e principalmente a moralização, já que as crianças eram consideradas como "projeto de adulto", estas deviam desde muito cedo, serem educadas conforme objetivos definidos pelos adultos, no entanto, não havia distinção entre literatura adulta e infantil, uma vez que visava moralizar a sociedade num todo.

Costa (2009, p. 113), nos esclarece que "nesse período remoto é que surgem as primeiras fábulas com animais, que representam virtudes e defeitos humanos". As fábulas de Esopo, com animais, fazendo o papel de humanos e com finalidade 
moral, atravessam os séculos e continuam até hoje a fazer parte da cultura, como por exemplo: A raposa e as uvas, A cigarra e a Formiga e A lebre a tartaruga.

Ainda segundo a autora, "os contos de fada facilitaram o uso do lúdico junto ao cognitivo voltado para o público infantil". Voltado dessa forma, para o desenvolvimento da psique infantil:

[...] estimula, nas crianças, interesses adormecidos que esperam que essa espécie de varinha mágica os desperte para aspectos do mundo que as rodeia; age sobre as forças do intelecto, como a imaginação ou o senso estético, que precisam do impulso de correntes exteriores para adquirir pleno desenvolvimento na evolução psíquica da criança. (JESUALDO apud COSTA, 2009, p. 116).

A citação de Costa (2009), nos permite inferir que através da literatura, a criança instrui-se, diverte-se, identifica-se com o mundo para formar suas capacidades intelectuais e sociais, pois ainda estão em processo de formação sobre suas experiências da realidade.

Sabendo que é na infância que a criatividade, e a imaginação são mais desenvolvidas, faz-se necessário que pais e professores retomem uma literatura herdada de povos seculares, que atravessou os anos, aquela na qual não se faz apelo para o consumo, pois na atualidade, a sociedade expressa-se utilitarista e capitalista.

Costa (2009, p. 118), nos diz que:

As histórias infantis favorecem a formação moral, social e literária dos leitores mirins, estabelecendo uma íntima relação entre o "segundo mundo", o da fantasia, no qual todas as crianças vivem em seus momentos de introspecção e a realidade, preparando esses pequenos leitores para operar a transposição do literário ao real. (COSTA, 2009, p. 118, grifo do autor).

Para o autor, através da literatura se passam valores às crianças, tais como, modo de agir diante de situações do cotidiano, como viver em sociedade, instruindo-os ao mesmo tempo em que forma suas capacidades intelectuais e sociais.

\section{LER PARA BEBÊS}

RC: 99019

Disponível em:

https://www.nucleodoconhecimento.com.br/educacao/desenvolvimento-afetivo 
Qual a real importância de se ler para bebês? Será que eles compreendem o que estamos lendo, conseguem assimilar o que a história lida quer representar? Ortiz (2012) nos lembra que não apenas o vocabulário da língua se amplia, mas todo o repertório simbólico para que o bebê possa interagir e compreender o mundo.

Sendo assim, segundo a autora, o bebê que desde cedo têm contato com o mundo da leitura, consegue expressar-se com mais clareza, possui um vocabulário mais amplo e comunica-se com mais facilidade. Nesse sentido, Faria (2010) apud

Ortiz (2012, p. 167, grifo do autor) explica que "Ler para os bebês ainda não falantes é uma prática que vem se consolidando cada vez mais, [...] Não há mais dúvida sobre a importância da narrativa na constituição psíquica do bebê, nem sobre o valor das histórias no aprendizado como um todo".

A criança começa a representar o mundo desde muito cedo, quanto mais cedo a leitura começar na vida dos pequenos, melhor. Não é apenas o vocabulário que se amplia, o repertório simbólico também, pois desta forma a criança pequena, interage e compreende o mundo de uma forma mais ampla, consegue elaborar soluções para as mais diversas situações que irão surgir no decorrer de sua vida.

A Literatura Infantil possui duas funções principais: a estética e a sensibilidade, pois reúne a beleza das imagens e a riqueza das palavras. Possari (2009) afirma que

A literatura contribui para a formação da criança em todos os aspectos: desde a formação de sua personalidade, o desenvolvimento estético e a capacidade crítica, garantindo-lhe a reflexão sobre seus próprios valores e crenças, e os da sociedade. (POSSARI, 2009, p. 56).

Sendo assim, percebemos a importância da literatura para o desenvolvimento da criança, tornando-a sensível e ao mesmo tempo crítica, refletindo diante de muitas situações que vivencia.

Sabemos que cada faixa etária tem suas especificidades, deve-se prestar muita atenção ao tipo de história a ser contada às crianças, pois quanto menor a idade, mais fácil ela se dispersa, desta forma, as crianças pequenas serão introduzidas ao 
mundo da leitura através de cantigas, pois elas gostam dos ritmos, entre afagos e ritmos, inicia-se o letramento literário da criança, quanto mais ritmo, movimento e sons repetidos, mais a criança se agrada e interage com o locutor.

Para Ortiz (2012, p. 169) a riqueza das ilustrações e o material de confecção dos livros para o berçário, devem ser de forma a tornar essa apresentação não só prazerosa, mas também segura, para que possam manuseá-los com liberdade e de todas as formas que quiserem, inclusive amassando e mordendo o material, práticas comuns nessa faixa etária. As diversas texturas contribuem para que o interesse pelo contato com o livro ocorra de forma mais intensa, uma vez que sejam de toque macio, como pelúcia, tecido, ou ainda de forma mais lúdica, como de plásticos infláveis, que fazem barulho, com luzes e sons.

\section{O PROFESSOR COMO AUXILIAR LITERÁRIO}

O professor deve estimular as crianças para construir uma relação afetiva com a Literatura Infantil, aprendendo o valor intelectual que cada obra tem. Favorecer o gosto pelas histórias, textos, poesias, entre outras obras literárias, implica a determinação do professor em promover momentos apropriados ao ato de contar e de ler histórias.

$\mathrm{Na}$ Literatura Infantil, devemos nos preocupar, principalmente, que a criança compreenda, goste e se divirta. Na prática pedagógica do professor, é importante que este se movimente ao contar histórias e recite poesias com entusiasmo, que dê entonações diferentes à voz. Todo o corpo precisa participar desse momento, por meio da gestualidade. O professor, ao contar histórias para as crianças, pode contribuir, efetivamente para despertar a motivação e o entendimento da obra. Para Possari (2009),

Quando o professor lê a criança escuta e acompanha as reações que serão transmitidas, mediante a emoção, a alegria, o medo, etc, então, nesse momento, a criança será muitas vezes, além de ouvinte, um coautor. Na arte de interpretar e no caso da criança que já lê, ela será o leitor ou intérprete. (POSSARI, 2009, p.56). 
Possari (2009) nos indica que o professor, como transmissor das ideias do livro, deve deixar com que as crianças participem desse ato tão importante que é a leitura, tanto como ouvinte quanto como leitor, desta forma, contribuirá para que essa criança não apenas ouça, mas participe desse momento e interprete o que foi lido e/ou ouvido.

\section{PERCURSOS METODOLÓGICOS}

A presente investigação é de abordagem qualitativa, sendo o método de estudo de caso, que segundo Lüdke (1986)

Entre as várias formas que pode assumir uma pesquisa qualitativa, destacamse a pesquisa do tipo etnográfico e o estudo de caso. Ambos vêm ganhando crescente aceitação na área de educação, devido principalmente ao seu potencial para estudar as questões relacionadas à escola. (LÜDKE, 1986, p.13).

Quando o pesquisador utiliza a abordagem qualitativa, ele estuda os problemas no ambiente em que eles acontecem, sem nenhum tipo de manipulação intencional, mantendo contato direto com o contexto investigado, nesse caso, a escola.

Como procedimentos de produção de dados, foram utilizados observação participante e entrevista estruturada com os professores, a fim de saber de que forma a Literatura Infantil é trabalhada com as crianças pequenas e como é vista a importância dessa prática pelo professor. Sobre a observação participante, Lüdke (1986) esclarece que esta pode ser parte essencial do trabalho na pesquisa qualitativa, é um processo em que o pesquisador observa uma situação e fica em contato direto com os interlocutores, participando da vida social do contexto em que está inserido, modificando-o e sendo modificado.

Segundo Preti (2012), a entrevista é uma conversação com um propósito, abarcando duas ou mais pessoas. Por isso sua forma de realização pode ser de natureza individual ou coletiva. Trata-se de técnica muita utilizada nas áreas das Ciências Humanas e Sociais na busca de informações diretamente com os atores sociais como sujeitos-objetos da pesquisa. Para Preti (2012)

RC: 99019

Disponível em:

https://www.nucleodoconhecimento.com.br/educacao/desenvolvimento-afetivo 
A entrevista estruturada, quando segue uma padronização de questões, cujos parâmetros são preestabelecidos, chegando quase a se confundir com um questionário oral. Em todos os entrevistados são feitas as mesmas perguntas e na mesma ordem (PRETI, 2012, p. 60).

$\mathrm{Na}$ entrevista estruturada, podemos pegar as respostas obtidas por todos os entrevistados e compará-las, sabendo assim, se todos possuem conhecimento sobre os assuntos abordados e de que forma os põem em prática.

A pesquisa foi realizada nos meses de abril e maio, e foi realizada de forma presencial. Para a realização das entrevistas, primeiramente, os participantes foram informados oralmente sobre o tema da pesquisa e, em seguida, foram feitas as perguntas pertinentes ao objetivo do trabalho. As perguntas foram de fácil compreensão e idênticas a todos os entrevistados.

No total, foram 05 professores entrevistados.

O contexto da pesquisa que deu origem a esse artigo, foi uma escola municipal de educação infantil do município de Matupá-MT. A entrevista foi realizada individualmente, de forma a propiciar ao professor toda liberdade para expressar suas opiniões. Por questões de ordem ética, o nome dos professores foi substituído por letras do alfabeto.

RC: 99019

Disponível em:

https://www.nucleodoconhecimento.com.br/educacao/desenvolvimento-afetivo 
Figura 1 - Escola Municipal de Educação Infantil Creche Criança Feliz

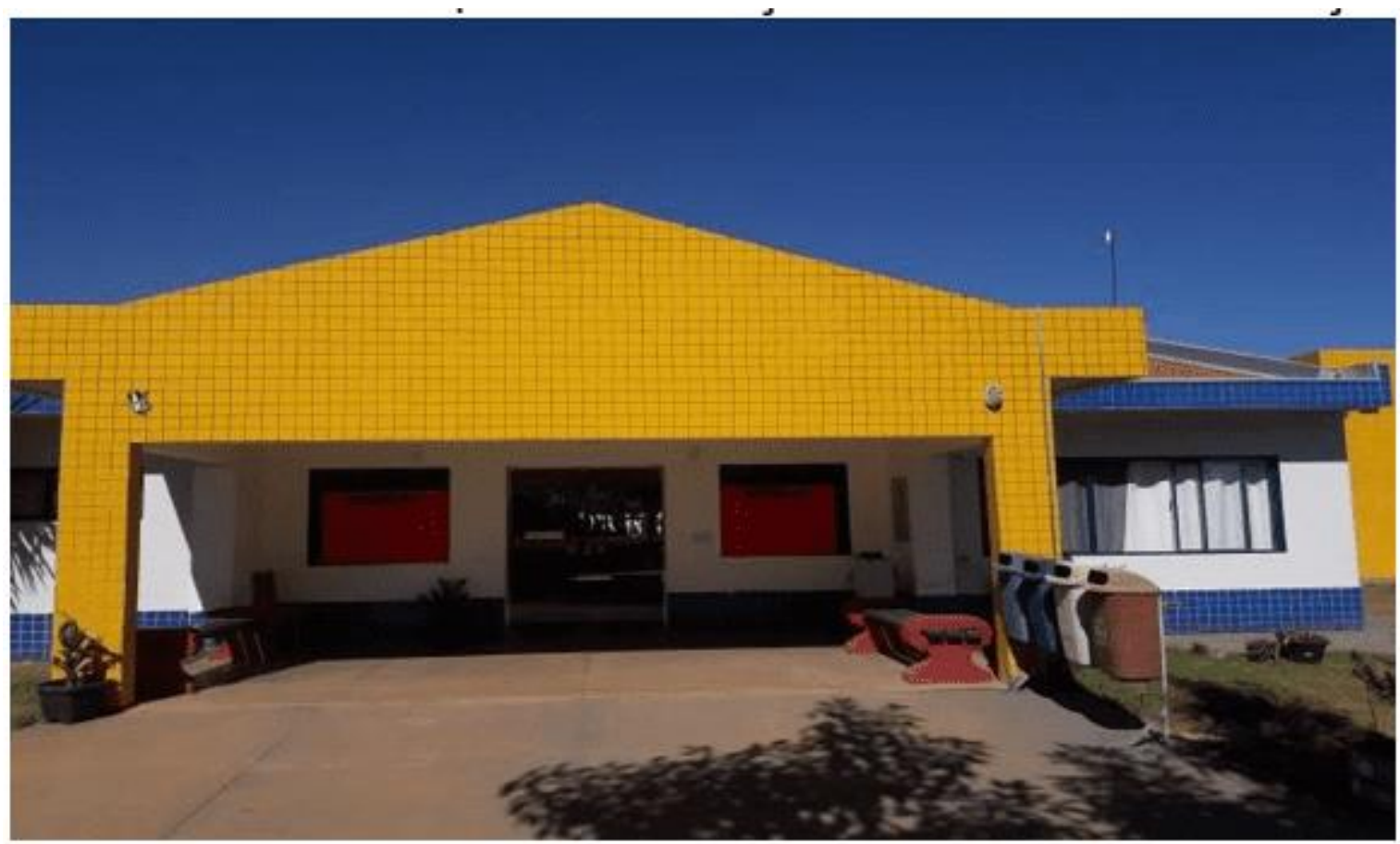

Fonte: arquivo do pesquisador.

$\mathrm{Na}$ figura 1, podemos observar o contexto em que foi realizada a pesquisa. A escola conta com 11 turmas no período matutino e 11 turmas no período vespertino, totalizando 22 turmas atendidas. Conta com 2 turmas de berçário 1, atendendo 10 crianças por turma; 6 turmas de berçário 2, atendendo 12 crianças por turma; 5 turmas de maternal 1 , atendendo 20 crianças por turma; 4 turmas de maternal 2 , atendendo 23 crianças por turma; 2 salas de pré 1 , atendendo 25 crianças por turma e 2 salas de pré 2, atendendo 25 crianças por turma; totalizando 384 crianças atendidas.

Para atender essa demanda, a escola conta com 22 professores pedagogos, 20 professores auxiliares, 02 técnicos administrativos, 07 profissionais de apoio administrativo, 01 coordenador pedagógico e 01 diretor. 


\section{RESULTADOS E DISCUSSÃO}

Ao analisar os dados, observamos que a maioria dos professores utilizam uma forma de organizar os alunos sentados em círculo, para que todos possam ver as imagens e também por que desta forma, conseguem mantê-los concentrados na história, já que devido a pouca idade, dispersam-se com facilidade, isto pode ser observado na fala do professor $A$.

Professor A: Primeiramente coloco as crianças sentadas em círculo no tatame e utilizo de livros com histórias curtas, com gravuras atrativas e coloridas, mostrando as imagens de acordo com a leitura para que possam compreender o que Ihes foi lido. (Entrevista realizada em 02 de maio de 2018).

O excerto acima corrobora Ortiz (2012), ao explicar que as rodas de histórias são momentos importantes para o desenvolvimento da linguagem oral, para aprender a ouvir, esperar o outro terminar de falar e que, embora as crianças não fiquem todas sentadas em círculo, devido o fato de algumas não ficarem muito tempo sentadas quietas, o jeito não importa muito, o essencial é que estas crianças estejam juntas e prestando atenção no assunto proposto pelo professor.

As crianças precisam gostar do momento da história, pois quando o professor lê com entusiasmo, as crianças, desde as menores, interagem com o livro.

RC: 99019

Disponível em:

https://www.nucleodoconhecimento.com.br/educacao/desenvolvimento-afetivo 
Figura 2 - Professor contando história para uma sala de berçário

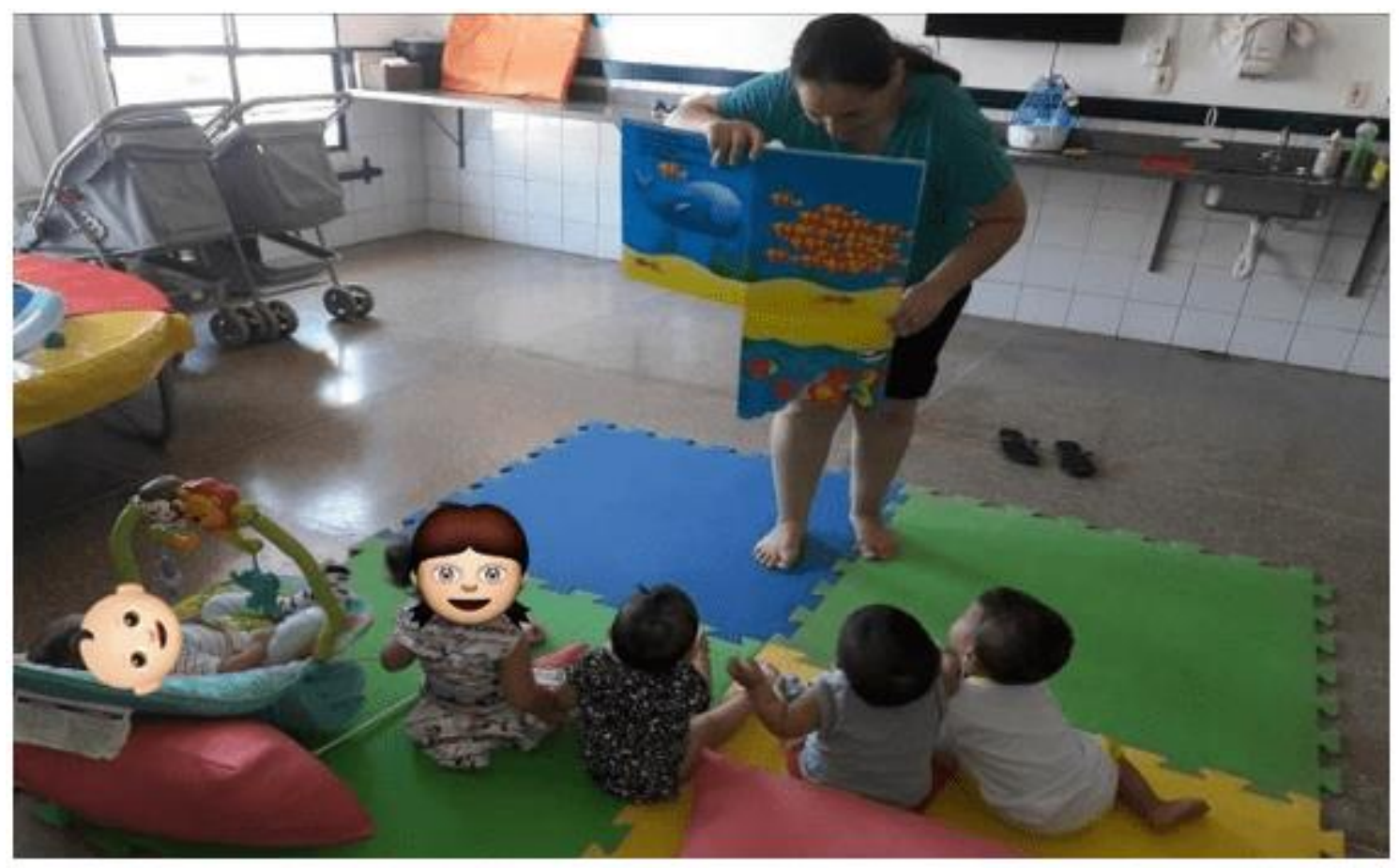

Fonte: arquivo do pesquisador

Os professores, na sua maioria, permitem que as crianças tenham contato direto com os livros, folheando-os, deixando que os explorem e interajam uns com os outros, verificamos isso na seguinte fala:

Professor B: Gosto de deixar que eles folheiem alguns livros, olhando suas gravuras e interagindo uns com os outros, após, pergunto dentre os livros que olharam, qual querem que eu leia. (Entrevista realizada em 02 de maio de 2018).

A fala acima confirma Ortiz (2012, p.168), ao falar que "No ambiente da creche, há que se priorizar os espaços de leitura, para que adultos leiam e mostrem livros para as crianças, [...] ler e apreciar figuras, manusear suas páginas, acompanhar sua história".

As crianças precisam ter contato com o livro, mesmo que ainda não saiba ler as palavras, fazem a leitura simbólica das imagens, assim, com o passar do tempo, começam a associar oralmente as imagens aos seus respectivos nomes. 
Figura 3 - Bebês interagindo com o livro durante a história

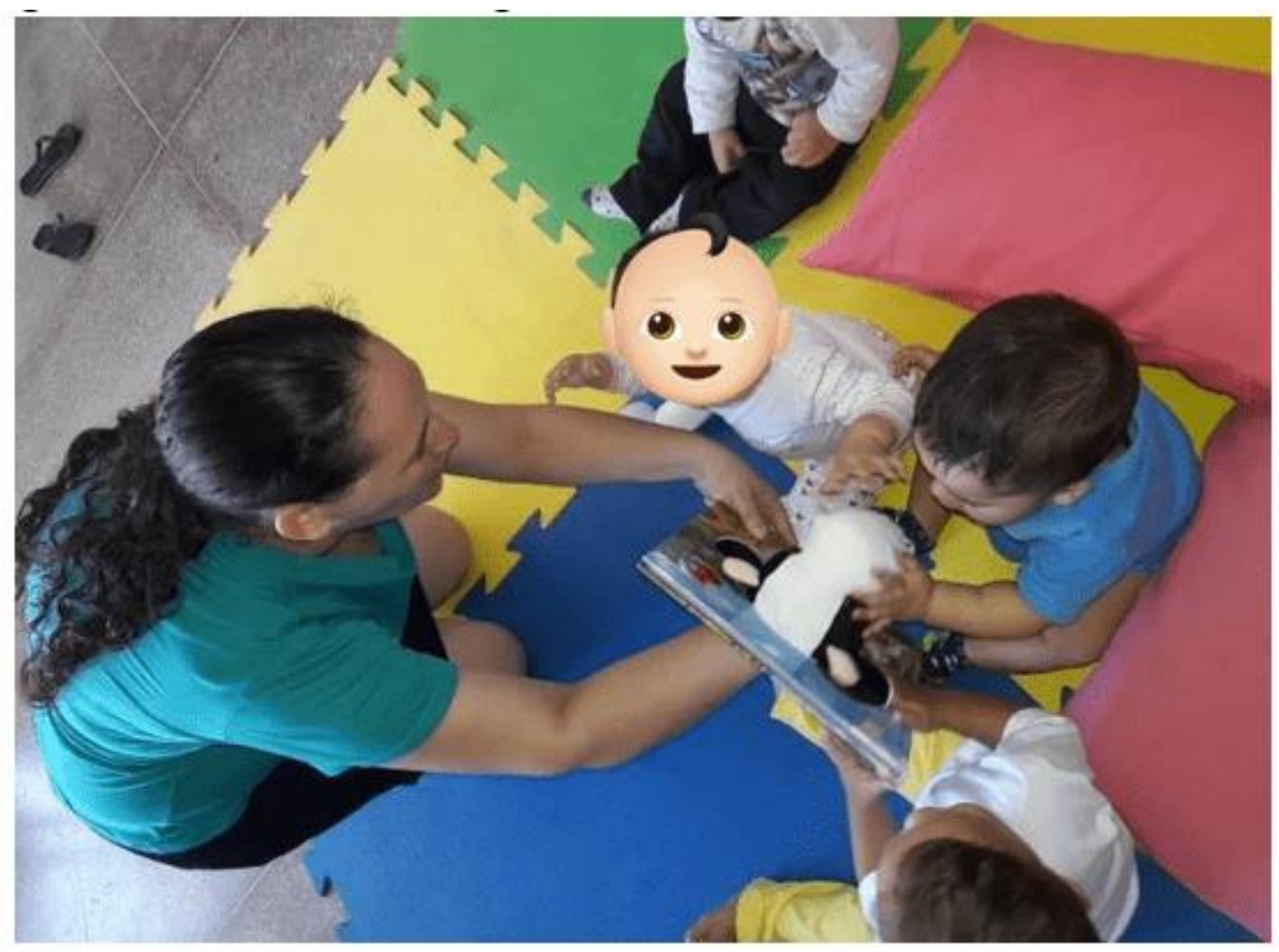

Fonte: arquivo do pesquisador

Observa-se na imagem acima, a interação dos bebês com o livro usado pelo professor durante a contação de história. O fantoche torna o livro mais interessante e estimula o contato visual.

A respeito de quando se deve iniciar a leitura com crianças pequenas, a maioria dos professores concordam que a literatura desde cedo na vida das crianças, desperta a imaginação, estimula a oralidade e a atenção, verificamos isso nas falas dos professores A e D:

Professor A: A criança que é inserida no mundo da leitura, terá mais facilidade em aprender, pois sua imaginação, oralidade e atenção são trabalhadas através dos livros. (Entrevista realizada em 02 de maio de 2018).

Professor D: Quando uma criança ouve uma história, ela entra nesse mundo de faz-de-conta, isso faz com que ela consiga associar aprendizados e aplicá-

RC: 99019

Disponível em:

https://www.nucleodoconhecimento.com.br/educacao/desenvolvimento-afetivo 
los no mundo real, como é o caso das fábulas. (Entrevista realizada em 02 de maio de 2018).

Podemos verificar nas falas acima que a imaginação é bastante estimulada durante a história e que as fábulas tornam a leitura divertida, já que os animais falam e comportam-se como seres humanos, trazendo sempre um ensinamento que poderá ser usado na vida real.

As falas acima concordam com Coelho (2000) explicando que

Desde as origens, a literatura aparece ligada a essa função essencial: atuar sobre as mentes, nas quais se decidem as vontades ou as ações; e sobre os espíritos, nos quais se expandem as emoções, paixões, desejos, sentimentos de toda ordem [...]. No encontro com a literatura (ou com a arte em geral) os homens têm a oportunidade de ampliar, transformar ou enriquecer sua própria experiência de vida, em um grau de intensidade não igualada por nenhuma outra atividade (COELHO, 2000, p. 29)

A importância da leitura na vida da criança é algo primordial, pois é através da leitura que o mundo se expande, que as oportunidades se revelam, pois, o fictício se mistura a realidade provocando um mix de sentimentos: medo, alegria, suspense, fazendo com que ela reflita sobre o que ouviu e decida sobre colocar ou não em prática.

Em relação de como a literatura é apresentada as crianças do berçário, observou-se que é apresentada através de livros específicos, constatamos isso nas falas dos professores B e C:

Professor B: Quanto menos idade têm, mais específicos são os livros. Por exemplo, para o berçário, faz-se uso de livros de tecido, emborrachado, plástico etc. pois sabemos que uma das primeiras ações dos bebês, é leválos à boca, por isso a importância de serem seguros, para serem explorados por eles. (Entrevista realizada em 02 de maio de 2018).

Professor C: Nos bebês precisamos estimular bastante a percepção visual, auditiva, assim como a coordenação motora, e através de livros coloridos e de materiais macios, tornamos esses aprendizados mais prazerosos e divertidos. (Entrevista realizada em 02 de maio de 2018). 
As falas dos professores $\mathrm{B}$ e $\mathrm{C}$ nos indicam que, os bebês precisam ter contato com os livros, livros que Ihes ofereçam liberdade para manuseá-los, para explorá-los, que sejam seguros ao mesmo tempo que são atraentes por suas imagens cheias de cor, pois nesse ato de leitura, todos os sentidos participam. Essa ideia corrobora Ortiz (2012) ao relatar que

Entendemos que os livros mais mordidos são os preferidos dos bebês, os que foram mais escolhidos. Acreditamos que no ambiente educacional, na interação com o adulto leitor, a criança vai aprender aos poucos a manusear esse livro de forma a não o rasgar, mas nesse primeiro momento o que importa é a experiência de tornar-se leitor e sabemos que ainda pequena, no período sensório, a criança lê com os olhos, ouvidos, mãos e boca, enfim, lê com todos os seus sentidos (ORTIZ, 2012, p. 169).

Sabemos que a primeira reação do bebê diante de algo que lhe chama a atenção, é levá-lo a boca, faz parte do seu desenvolvimento, pois é a fase de experimentação, onde tudo vai a boca. No entanto, é tudo uma questão de hábito, aos poucos vão aprendendo a folhear, observar mais as imagens, e o processo de construção do hábito de leitura vai aos poucos se consolidando. 
Figura 4 - Livros utilizados na sala de berçário

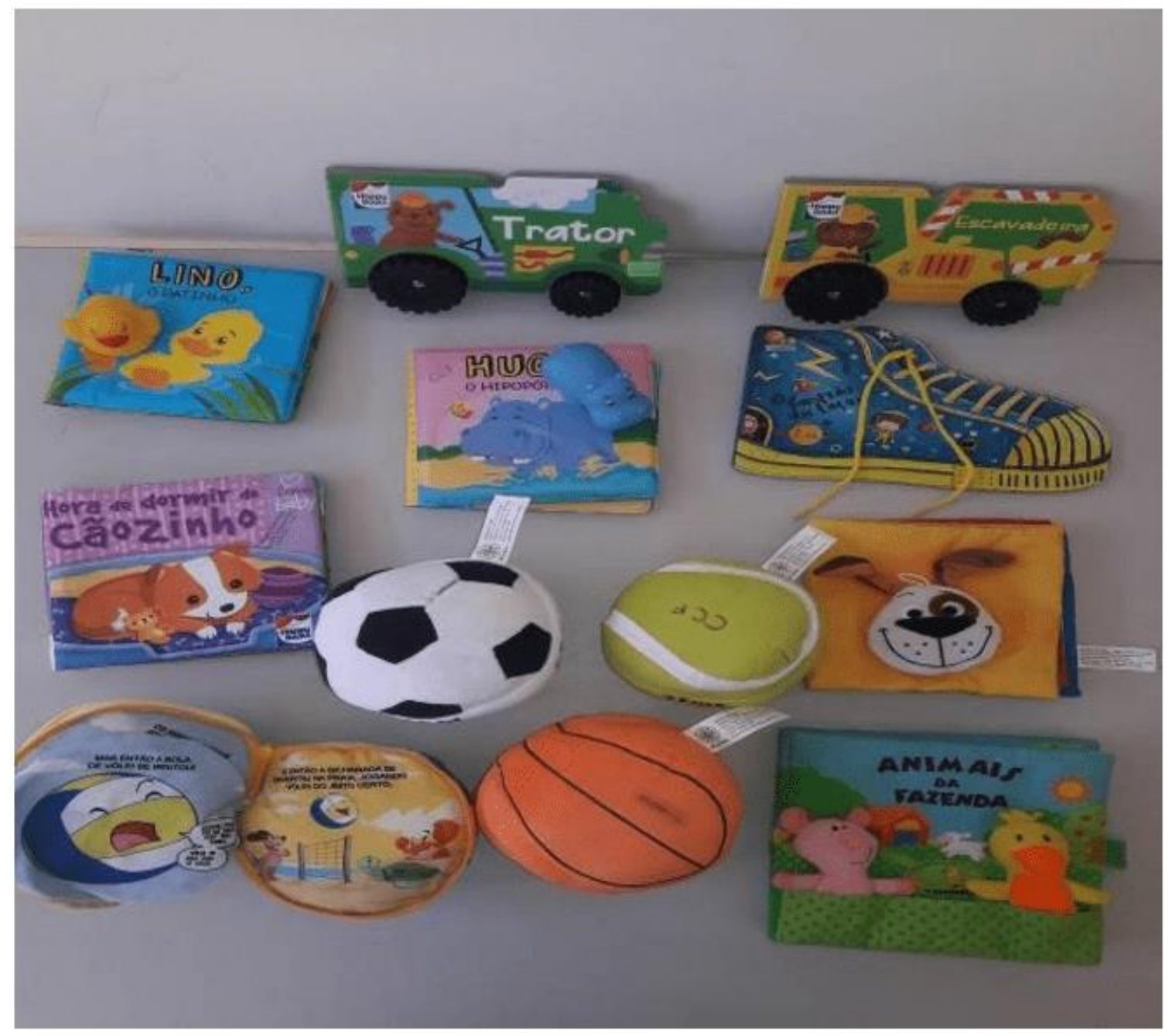

Fonte: arquivo do pesquisador

$\mathrm{Na}$ imagem acima podemos observar livros usados para a contação de histórias com os bebês, livros de materiais diversos, de texturas diferentes, despertando a curiosidade e fazendo com que sejam seguros para essa faixa etária.

Observamos alguns dos tipos de livros mais utilizados pelos professores para ler para as crianças. Os livros coloridos e com gravuras grandes, com fantoches, facilitam na hora da leitura, pois chama a atenção, os livros que possuem luzes, música e que fazem barulho e os livros em 3D também são bastante utilizados, pois 
apresentam movimento, prendendo a atenção deles, observamos isso na fala do professor $\mathrm{E}$ :

Professor E: As crianças amam livros coloridos, cheios de imagens, livros que ao abrir, revelam o cenário e os personagens, que parecem ter vida, que parecem mágicos, mas na verdade, são mesmo! (Entrevista realizada em 02 de maio de 2018).

Desta forma, podemos perceber que a imagem tem papel fundamental nos livros direcionados às crianças pequenas, que desde muito cedo, conseguem fazer essa leitura criadora. Nesse sentido Abramovich (1997, p.33) traz que,

livros (feitos para crianças pequenas, mas que podem encantar aos de qualquer idade) são sobretudo experiências de olhar... De um olhar múltiplo, pois se vê com os olhos do autor e do olhador/leitor, ambos enxergando o mundo $\mathrm{e}$ as personagens de modo diferente, conforme percebem esse mundo... (ABRAMOVICH, 1997, p.33).

Aos poucos as crianças pequenas começam a relacionar o que ouve com o que vê, relacionando os nomes das figuras, nas primeiras palavras, por isso a importância de o livro ser atrativo.

RC: 99019

Disponível em:

https://www.nucleodoconhecimento.com.br/educacao/desenvolvimento-afetivo 
Figura 5 - Bebês explorando livro

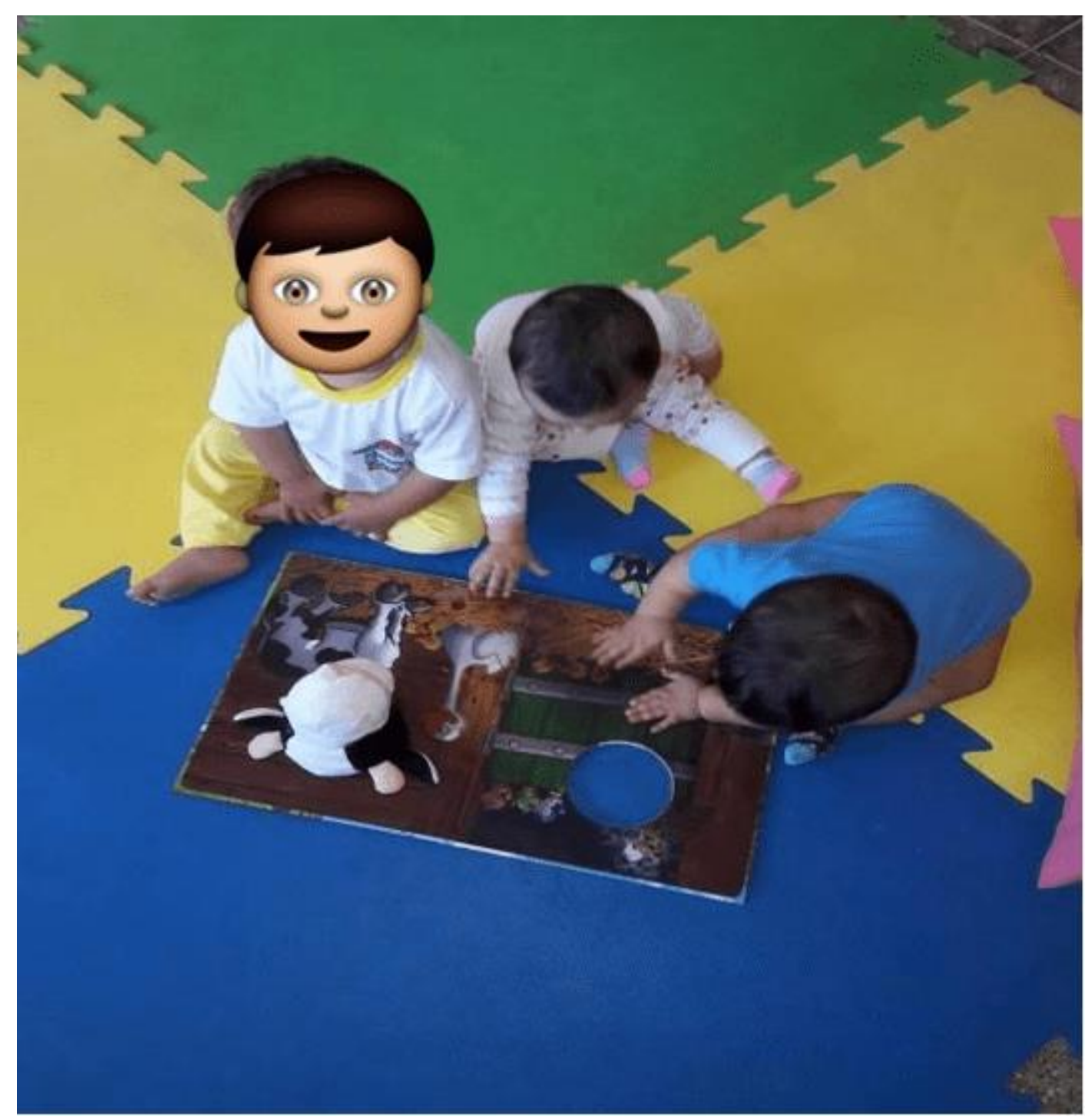

Fonte: arquivo do pesquisador

RC: 99019

Disponível em:

https://www.nucleodoconhecimento.com.br/educacao/desenvolvimento-afetivo 
Figura 6 - Alguns livros utilizados na leitura das crianças

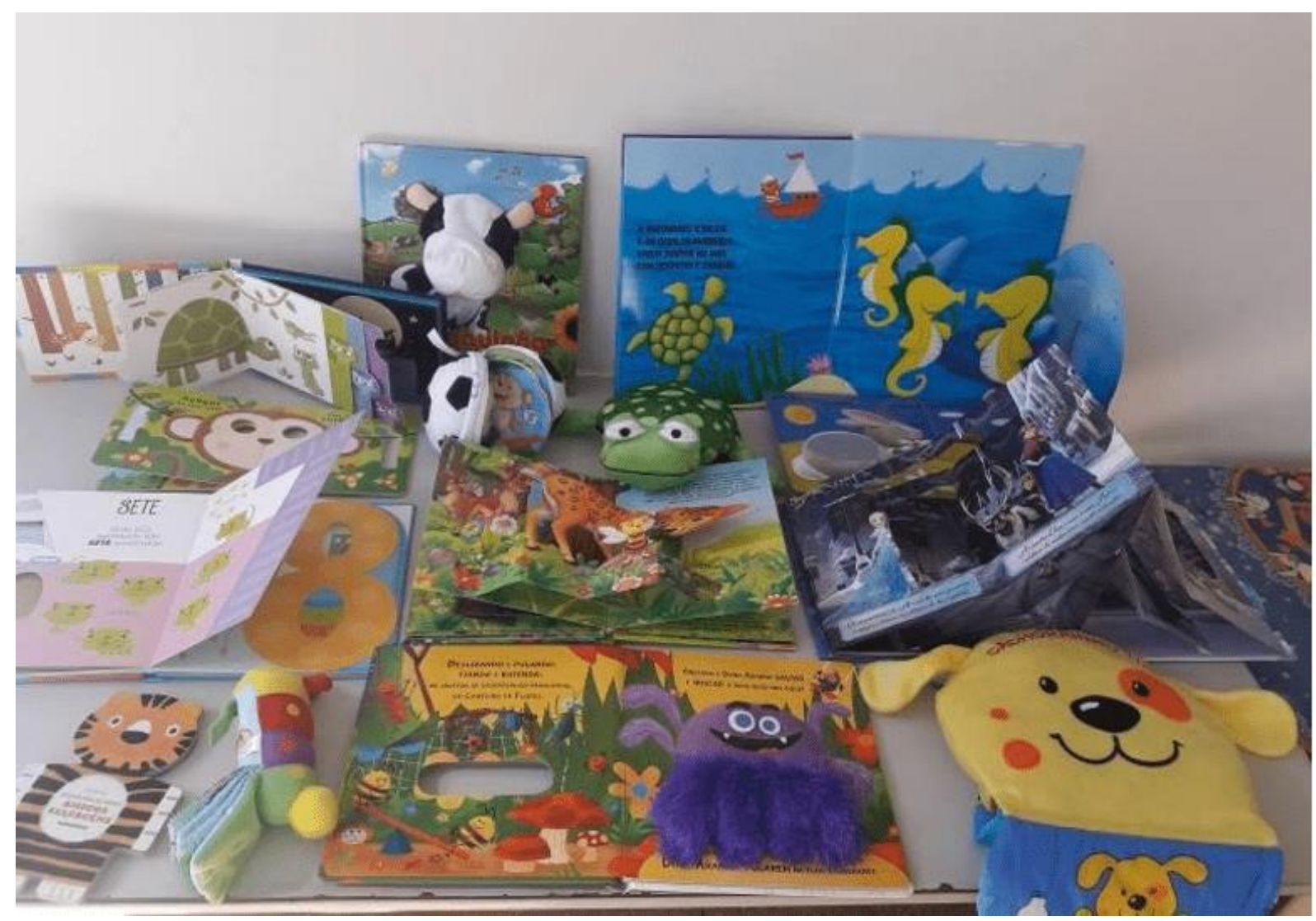

Fonte: arquivo do pesquisador

$\mathrm{Na}$ imagem acima, percebemos a diversidade de livros infantis. $\mathrm{O}$ formato, textura $\mathrm{e}$ cores vivas tornam o material mais atraente para as crianças. Esses livros são usados diariamente pelos professores, pois todo dia é dia de leitura!

Os professores estimulam a prática da leitura com as crianças diariamente, podemos observar isso na fala do professor B:

Professor B: Sempre início a aula com a leitura de uma história, depois pergunto de que parte gostaram mais, assim, interagem comigo e eu sei se prestaram atenção. (Entrevista realizada em 02 de maio de 2018).

Costa (2009, p. 54) nos alerta "Quando o professor assume a compreensão das interfaces da leitura e aplica estratégias para que os alunos consigam percebê-las, a atuação docente [...] resulta na construção de projetos progressivos de leitura". 
É de fundamental importância que o professor faça da leitura um hábito, mostrando às crianças, o quanto é divertido ler, e através da leitura, ter muitas descobertas.

A respeito de que forma a família pode refletir nesse processo de leitura, os professores disseram que na família onde se têm o hábito da leitura, a criança já traz isso consigo, ela gosta dos livros, de ouvir as histórias, possui um vocabulário mais amplo e consegue expressar-se melhor, constatamos isso na fala dos professores $\mathrm{C}$ e D:

Professor C: Dá para perceber quando a família tem hábito de leitura, até o vocabulário da criança é mais rico, variado, a criança possui até mais facilidade em expressar-se. (Entrevista realizada em 02 de maio de 2018).

Professor D: A família que lê, transmite esse valor para a criança, ela comunica-se bem, até nas apresentações da escola, ela geralmente é mais desinibida. (Entrevista realizada em 02 de maio de 2018).

Fica claro ao analisarmos as falas dos professores, que a família possui grande influência na introdução da leitura na vida da criança, considerando que é na família que se adquire os primeiros hábitos, isso faz parte da referência de família leitora que a criança traz de casa.

Costa (2009, p. 52) enfatiza que

A escola, mesmo que realize um trabalho competente de formação, não conseguirá consolidar o leitor sem o respaldo da sociedade que a sustenta. [...] a família, embora se posicione a favor, não lê e interfere negativamente no trabalho de formação do leitor, ao privilegiar formas de lazer que, pensa ela, trazem maior prazer do que a leitura.

Desta forma, podemos perceber o quão importante é a participação nesse processo de formação do leitor, pois todo o âmbito familiar pode refletir positivamente, quanto negativamente, o resultado depende da forma em que lhe é dada a devida importância. 


\section{CONSIDERAÇÕES FINAIS}

De acordo com a análise dos dados apresentada neste trabalho, concluiu-se que a literatura é parte essencial no desenvolvimento do gosto pela leitura na criança. Ou seja, observou-se que a literatura, na Educação Infantil, auxilia diretamente no vocabulário e na comunicação oral, bem como desperta na criança o interesse pela leitura e contribui diretamente na formação do futuro leitor. Quando o aluno aprecia um livro e mostra as imagens a um colega, constrói um vínculo afetivo e social, pois está compartilhando algo naquele contexto.

A literatura como forma de desenvolvimento afetivo, cognitivo e social na educação infantil, está sendo utilizada e desenvolvida e o professor consegue perceber isso, através das reações das crianças e através de sua sensibilidade docente em perceber, que além dele, o vínculo família/escola torna o aprendizado mais significativo, pois a socialização ocorre de maneira satisfatória.

Foi possível constatar também, que a utilização de livros ilustrados, com músicas e luzes, favorece o interesse das crianças pequenas, faz com que queiram estar em contato com eles, facilitando assim, o processo de iniciação à leitura.

Desse modo, respondendo a questão norteadora - o pedagogo, fazendo uso da literatura, consegue perceber o desenvolvimento afetivo, cognitivo e social das crianças? - concluímos que os professores conseguem perceber a literatura como forma de desenvolvimento afetivo, cognitivo e social na educação infantil, relatando através das entrevistas realizadas que esta possui grande importância no aprendizado das crianças e que esse é um dos meios mais eficazes para a construção do conhecimento, pois é a partir dela que a criança irá despertar o gosto pela leitura e consequentemente no futuro, terá um melhor desenvolvimento na escrita. Bem como, constatou-se que, os professores buscam metodologias e recursos diversos para, de maneira mais prazerosa e produtiva, auxiliar as crianças nesse processo de desenvolvimento do gosto pela leitura, pela afetividade e 
socialização entre elas, assim como também entre aluno e professor, fazendo que com isso, torne-se um adulto detentor de respeito mútuo.

\section{REFERÊNCIAS BIBLIOGRÁFICAS}

ABRAMOVICH, F. Literatura Infantil - gostosuras e bobices. São Paulo: Scipione, 1997.

COELHO, N. N. Literatura Infantil: Teoria Análise Didática. Edit. Moderna,1ํㅡ. Ed. São Paulo: 2000.

COSTA, M. M. Literatura Infantil. $2^{\underline{a}}$ ed. Curitiba: IESDE Brasil S.A. 2009.

CRAMER, E. H.; CASTLE, M. Incentivando o amor pela leitura. Porto Alegre: Artmed, 2011.

LÜDKE, M. Pesquisa em educação: abordagens qualitativas. São Paulo: EPU, 1986.

ORTIZ, C. Interações: ser professor de bebês: cuidar, educar e brincar: uma única ação. São Paulo: Blucher, 2012.

POSSARI, L. H. V. Múltiplas linguagens: pensamento e linguagem. Cuiabá: EdUFMT/UAB, 2009.

PRETI, O. Pesquisa em Educação. 4ª ed. Cuiabá: EdUFMT, 2012.

Enviado: Agosto, 2021.

Aprovado: Outubro, 2021.

RC: 99019

Disponível em:

https://www.nucleodoconhecimento.com.br/educacao/desenvolvimento-afetivo 